\title{
Technologies for Enhancement of Shares in Online Trading
}

\author{
T. Subhalatha, M. Shanmuga Priya, C. Archanapriya
}

\begin{abstract}
To know about the success criteria of the women entrepreneurs. Today women are empowered in various aspect of life, to know the challenges that had been faced by the women entrepreneurs. Customer perception has been clearly examined among the customer of the women entrepreneurs In online stock broking. As the male domination is more in this area, to know the customer perception towards women entrepreneurs rather with the male entrepreneurs. The factors that motivates the women in entrepreneurial development. As there are remarkable change in the upliftment of women, the success strategies will help the upcoming women entrepreneurs to excel in the business.

Women are considered as eyes of the nation. Women achieving greater heights in all sectors. The study aims to identify the success strategies, challenges that had been pursued by the women entrepreneurs to achieve a zeal. To understand this a structured questionnaire was prepared and collected among the women entrepreneurs in and around Chennai city. According to the response of the women entrepreneur's analysis and interpretation was made and suggestion were made. It helps other women entrepreneurs to have a literature about the strategies.
\end{abstract}

Keywords: Empowerment, Entepreneurs, Structured Questionnaire.

\section{INTRODUCTION}

Women are considered as eyes of the nation. Women achieving greater heights in all sectors. The study aims to identify the success strategies, challenges that had been pursued by the women entrepreneurs to achieve a zeal. To understand this a structured questionnaire was prepared and collected among the women entrepreneurs in and around Chennai city[1]-[4]. According to the response of the women entrepreneur's analysis and interpretation was made and suggestion were made. It helps other women entrepreneurs to have a literature about the strategies.

\section{OBJECTIVES}

1. To investigate the strategies pursued by women entrepreneurs to face their challenges and succeed in their online share broking

2. To find the supporting factors that motivates women entrepreneurs in online share trading.

Revised Manuscript Received on December 11, 2019

T. Subhalatha, Department of Science and Humanities, Bharath Institute of Higher Education and Research, Chennai , India. Email: subhalatha.thavasikannan@gmail.com

M. Shanmuga Priya, Department of Science and Humanities, Bharath Institute of Higher Education and Research, Chennai, India. Email: priyashammu@gmail.com

C. Archanapriya, Department of Science and Humanities, Bharath Institute of Higher Education and Research, Chennai, India. Email: Archanapriya854@gmail.com
3. To identify the challenges those are faced by women entrepreneurs in online share trading.

4. To identify how far the women entrepreneurs servicing their clients in online share trading.

\section{A. Scope of the Study}

The study helps the women entrepreneurs to have a literature insight with the practical results of the success criteria. With this the women entrepreneurs can have their success in their business[5]-[7]. As an online share trading is a upcoming new sector for the women to excel as the timing involved and the work stress will be less. So this study will help other women entrepreneurs to know about the success factor.

\section{RESEARCH METHODOLOGY}

\section{A. Sampling Design}

Sampling is the main process in research process. Information had been collected from the respondent (women Entrepreneurs) from various part of Chennai. 300 questionnaire were circulated through various stock broking agency and through phone contacts of the share brokers and also through mails. 300 filled in questionnaire was responded. So the sample size of the research had been 300 . Convenience sample design have been used.The questionnaire had been framed with the objectives framed for the research purpose[8]-[10].

\section{B. Statistical tools used}

The various statistical tool such as percentage analysis, descriptive analysis, f-test, chi-square and linear multiple regression are used.

\section{Period of the study}

The present period of the study for the research work is for one month.

\section{Sources of Data}

Primary and secondary data were used for study purposes. The primary data was collected by questionnaire from the female entrepreneurs. Secondary data from books, newspapers and websites were collected.

\section{E. Limitation of the study}

1. The study is limited with the period of one month.

2. The data collected is limited to 300 respondent but it is not the information as a whole women entrepreneur.

3. The study is made within a period of one month, so the findings will not be applicable for more years.

4. The area of the research is limited only with Chennai 


\section{RESULTS AND DISCUSSIONS}

\section{A. Findings from Socio-Economic and Demographic Factors}

1. Majority of the assenters are belong to the age group of 41-50 years

2. Very few assenters belong to the Educational Qualification of Vocational Education

3. Maximum respondents spend their office hours for trading

4. Few respondents consider their source of income as the primary objective of investment[11]-[14]

5. Maximum respondents begin an online share trading through the reference from their friends

6. Maximum respondents spend 2-3 years in online trading

\section{B. Findings from Women Entrepreneurship Variables}

1. Majority of the respondents have shortage of infra structure

2. Almost all respondents are motivated by Income generation

3. Maximum respondents have Financial Constraints as their major challenge in entrepreneurship

4. Very few respondents are irregularly working in online share trading

5. Majority of the respondents agrees Economic growth is the contribution of women towards entrepreneurial development 6. Majority of the respondents are feeling easy to operate

7. Very few of the respondents prefer Newspaper as the media of advertisement

8. Almost all respondents are having prior experiences in online trading before starting the new concern

9. Very few respondents have self-motivation as their supporting factor[15]-[19]

10. Almost all respondents are moderately successful with entrepreneurship

\section{Findings from Descriptive Analysis}

The overall mean score of the variables on Success criteria of Women Entrepreneurship are 5.0096 which actually revealed that majority of the respondents strongly agreed Support from family, Personal freedom, Social recognition, security; internal motivation and Knowledge of information technology are the major success criteria for women entrepreneurship[20]

\section{Findings from the Testing of Hypotheses for the study}

1. There is noteworthy distinction between Age of the respondents and achievement level of the Women Entrepreneurs

2. There is noteworthy contrast between Educational Qualification of the respondents and achievement level of the Women Entrepreneurs.

3. There is huge contrast between Trading Hours of the respondents and achievement level of the Women Entrepreneurs.

4. There is huge contrast between Beginning Induction of the respondents and achievement level of the Women Entrepreneurs.

5. There is noteworthy distinction between Online Trading Experience of the respondents and achievement level of the Women Entrepreneurs.
6. There is huge relationship between Factors that spurs ladies to become business visionary and achievement of the Women Entrepreneurs

7. There is noteworthy relationship between Major difficulties looked by ladies and achievement level of the Women Entrepreneurs

8. There is noteworthy relationship between Frequency of online offer exchanging and achievement level of the Women Entrepreneurs

9. There is huge relationship between Contributions of ladies towards innovative advancement and achievement level of the Women Entrepreneurs

10. There is significant association between Prior experience in online trading before starting the new concern and success level of the Women Entrepreneurs

11. There is significant association between supporting factors of entrepreneurship and success level of the Women Entrepreneurs[21]

12. There is significant influence between Demographic factors (except Educational qualification and Easy and fast way of trading) and success level of the Women Entrepreneurs.

\section{SUGGESTIONS}

The suggestions for the study are vital to provide better insight of measures to be taken to rectify the problems of the research work undertaken. With regards to the findings of the present study the researcher has listed practical recommendations for the study conducted[22]-[23].

1. Women entrepreneurship in each and every part of the nation needs to be highly considered and should have a continuous attempt to inspire, encourage, motivate and cooperate women entrepreneurs to provide best productive outcomes in all the efforts they take.

2. A mass-scale awareness campaign should be implemented with the intention of raising awareness among women about the different areas for conducting business, especially in creative business such as online share trading.

3 . There should be efforts to improve women's education requirements in particular and to make effective arrangements for their learning, practical experience and personality development programs to improvise their overall standards of personality.

4. Extending vocational training for women to allow them to understand the production process and manage production. The area such as online trading needs to be initiated by the ministries of government.

5. International, National, Local trade fairs, Industrial introductions, workshops and gatherings should be dealt with to help women with encouraging participation with different women representatives.

6. Women in business should be offered sensitive advances and subsides for engaging them into current works out. The money related foundations should give all the additionally working capital assistance both for little scale experience and immense scale undertakings.

7. By different plans, the flimsier region can collect funds and convince the company to make business visionaries in the country. 
For eg, the Prime Pastors RozgarYojana, the Khadi and Rural City undertakings story, so on. In the underlying stages ladies business people can address issues however they should move ahead, have self-confidence and not surrender midway.

8. Attempts by various NGOs and government associations to disseminate data on arrangements, plans, and systems for women's improvement in industry, exchange, and business. The various plans given by the government should be used by business visionaries[24].

9. Self-help conferences of female business visionaries to collect resources and pool capital assets in order to assist women in the field of manufacturing, exchange and trade can also take on a constructive job to take care of this issue.

\section{CONCLUSION}

Women entrepreneurship is the sustainable source for any developing economy. Especially, the entrepreneurial initiative in the technological side is significantly impressive. Online share trading is quite trending in the present scenario. Women in the Metro cities are much affinity towards technology oriented business in nature. Women entrepreneurs in the online share trading business are something uncommon for the beginners of the field runner.

The present study majorly concentrated on the success level of the women entrepreneurs in the Chennai city. The outcome of this research work is fruitful which enables to find solution for the research problem chosen for the study. The objectives of the study are scientifically satisfied through varied analysis and tests[25]. The study revealed that there is significant relationship between the demographic factors of the respondents, which helps us to understand the holistic approach of the women entrepreneurship in existence.

Online share trading is the significant area which needs to be explored by more women entrepreneurs in upcoming period which encourages sustainable economy in the nation. Ministry of Women empowerment, Policies and Programmes of Entrepreneurial development cells should reach more emphasize and establishment in favour of Women's innovative and technical entrepreneurial initiatives in the country.

\section{REFERENCES}

1. Vasanthi, S. \& Rabiyathul Basariya, S. 2019, "Influence of value analysis and cross training in industry", International Journal of Engineering and Advanced Technology, vol. 8, no. 6, pp. 1810-1811.

2. Velvizhi, R., Sri Gowtham, S. \& Jeya Priya, D. 2019, "Examination of early feedbacks for effective product retailing on E-commerce websites", International Journal of Engineering and Advanced Technology, vol. 8 , no. 6 Special Issue 2, pp. 703-706.

3. Anuradha, C., Pothumani, S. \& Kavitha, R. 2019, "A novel method towards E-commerce", International Journal of Engineering and Advanced Technology, vol. 8, no. 6 Special Issue 2, pp. 535-538.

4. Thomas, J. \& Rabiyathul Basariya, S. 2019, "A study on the issues of financial ratio analysis", Indian Journal of Public Health Research and Development, vol. 10, no. 3, pp. 1079-1081.

5. Ramachandran, S. \& Rabiyathul Basariya, S. 2019, "Online marketing - study on customer satisfaction and relationship", Indian Journal of Public Health Research and Development, vol. 10, no. 3, pp. 1072-1078.

6. Priya, R., Vinothini, G. \& Cor Jesu, C.D. 2019, "The mentor-protégé relationship for professional growth", Journal of Advanced Research in Dynamical and Control Systems, vol. 11, no. 9 Special Issue, pp. 1110-1119.
7. Jannifer Rani, N., Bina Pani, S. \& Nimisha, N.S. 2019, "A study on money back polices available in LIC", Journal of Advanced Research in Dynamical and Control Systems, vol. 11, no. 9 Special Issue, pp. 833-839.

8. Saillaja, V., Jhansi Rani, K. \& Catherine, R. 2019, "Global marketing management planning and organization", Journal of Advanced Research in Dynamical and Control Systems, vol. 11, no. 9 Special Issue, pp. 489-493.

9. Saillaja, V., Jhansi Rani, K. \& Catherine, R. 2019, "The new phase of marketing information system", Journal of Advanced Research in Dynamical and Control Systems, vol. 11, no. 9 Special Issue, pp. 482-488.

10. Thoufiqulla \& Raju, D.V. 2019, "Perception of indian investor towards investment in mutual funds with special reference to mip funds", Journal of Advanced Research in Dynamical and Control Systems, vol. 11, no. 5, pp. 177-183.

11. Jasmine, K.R.M. \& Basariya, S.R. 2018, "A study on the customers benefits on mutual funds", International Journal of Civil Engineering and Technology, vol. 9, no. 4, pp. 45-48

12. Vasanthi, S. \& Basariya, S.R. 2019, "Pros and cons of on the job training versus off the job training", International Journal of Scientific and Technology Research, vol. 8, no. 10, pp. 671-674.

13. Pavithra, J. \& Ganesan, M. 2016, "A study on awareness and impact of micro-financial schemes", International Journal of Applied Business and Economic Research, vol. 14, no. 8, pp. 5449-5460.

14. Pavithra, J., Dilli Babu, P. \& Ambuli, T.V. 2014, "A study on budgetary control at Maruti Service Masters, Chennai", International Journal of Applied Business and Economic Research, vol. 12, no. 2, pp. 151-161.

15. Gunaraja, T.M. \& Venkatrama Raju, D. 2018, "Determining factors of organisational climate with reference to leadership styles", International Journal of Mechanical Engineering and Technology, vol. 9, no. 9, pp. 1327-1332.

16. Gunaraja, T.M. \& Venkatrama Raju, D. 2018, "The role of job satisfaction and training of employees in determining organisational climate of a selected industry", International Journal of Civil Engineering and Technology, vol. 9, no. 8, pp. 1266-1269.

17. Aarathy, T.S. \& Raju, D.V. 2018, "Performance appraisal and its effects on employees with respect to it sector in Chennai city", Internationa Journal of Civil Engineering and Technology, vol. 9, no. 6, pp 1535-1538.

18. Aarathy, T.S. \& Raju, D.V. 2018, "Employee perception towards performance appraisal system in IT sector", International Journal of Mechanical Engineering and Technology, vol. 9, no. 5, pp. 131-135.

19. Porselvi, W., Jublee, D. \& Sivanesan, G. 2018, "A study on factors influencing adoption of technology and innovation in banking industry, tamilnadu, India", International Journal of Mechanical Engineering and Technology, vol. 9, no. 5, pp. 789-800.

20. Akessa, G.M. and Dhufera, A.G., 2015. Factors That Influences Students Academic Performance: A Case of Rift Valley University, Jimma, Ethiopia. Journal of Education and Practice, 6(22), pp.55-63.

21. Miller, G. and Shih, C.C., 1999. A faculty assessment of the academic rigor of on-and off-campus courses in agriculture. Journal of Agricultural Education, 40, pp.57-65.

22. Tsinidou, M., Gerogiannis, V. and Fitsilis, P., 2010. Evaluation of the factors that determine quality in higher education: an empirical study. Quality Assurance in education, 18(3), pp.227-244.

23. Farooq, M.S., Chaudhry, A.H., Shafiq, M. and Berhanu, G., 2011. Factors affecting students' quality of academic performance: a case of secondary school level. Journal of quality and technology management, 7(2), pp.1-14.

24. Fitsilis, P., Gerogiannis, V. and Anthopoulos, L., 2014. Ontologies for software project management: a review. Journal of Software Engineering and Applications, 7(13), p.1096.

25. Adams, J.D. and Jaffe, A.B., 1996. Bounding the effects of R\&D: an investigation using matched establishment-firm data(No. w5544). National bureau of economic research.

\section{AUTHORS PROFILE}

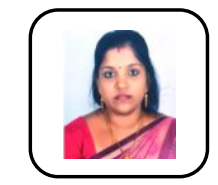

T. Subhalatha, Assistant Professor, Department of Science and Humanities, Bharath Institute of Higher Education and Research, Chennai, India. 
M. Shanmuga Priya, Assistant Professor, Department of Science and Humanities, Bharath Institute of Higher Education and Research, Chennai , India.

C. Archanapriya, Assistant Professor, Department of Science and Humanities, Bharath Institute of Higher Education and Research, Chennai , India. 